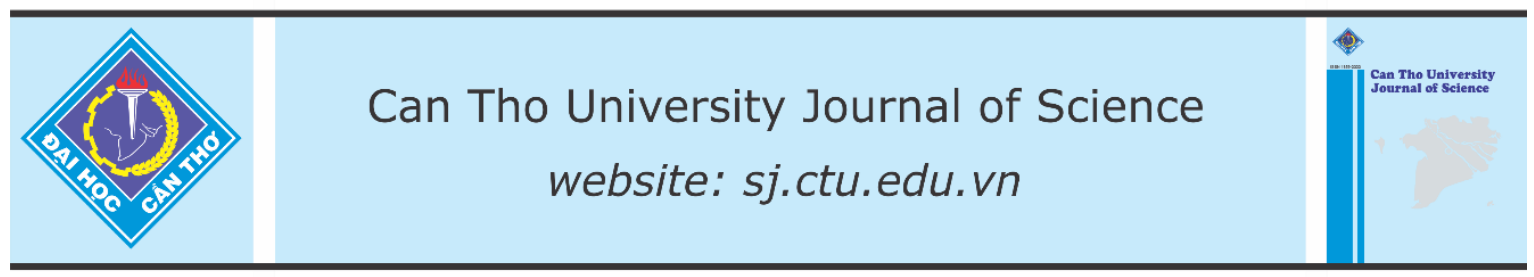

DOI: 10.22144/ctu.jen.2021.004

\title{
Climate change-related risk adaptation in striped catfish, tilapia and shrimp farming systems in the Mekong Delta, Vietnam
}

Vo Nam Son ${ }^{1 *}$, Dao Minh Hai ${ }^{1}$, Nguyen Do Quynh ${ }^{1}$, Long Van Nghia ${ }^{4}$, Phan Thi Thanh Truc ${ }^{5}$,

Nguyen Quynh Anh ${ }^{3}$, Do Thi Thanh Huong ${ }^{1}$, Boripat Lebel ${ }^{2}$, Louis Lebel ${ }^{2}$ and Nguyen Thanh Phuong ${ }^{1}$

${ }^{1}$ College of Aquaculture and Fisheries, Can Tho University, Vietnam

${ }^{2}$ Unit for Social and Environmental Research, Chiang Mai University, Thailand

${ }^{3}$ National Institute for Science and Technology Policy and Strategy Studies, Ministry of Science and Technology, Vietnam

${ }^{4}$ Bac Lieu Agricultural High-Tech Part in Application to the Development of Shrimp, Vietnam

${ }^{5}$ School of Agriculture and Aquaculture, Tra Vinh University, Vietnam

*Correspondence: Vo Nam Son (email: vnson@ctu.edu.vn)

\section{Article info.}

Received 17 Oct 2020

Revised 01 Dec 2020

Accepted 31 Mar 2021

\section{Keywords}

Adaptation, climate changerelated risks, shrimp, striped catfish, tilapia, farming

\section{ABSTRACT}

This study aims to determine climate change-related risk (CCR) impacts, responses of farmers, and assistant activities in tilapia cage culture (TC), striped catfish nursery (SCN), striped catfish grow-out (SCG), improved extensive shrimp (IES) and intensive shrimp (IS) systems. A survey of 601 farmers in the Mekong Delta, Vietnam, was conducted using clustered sampling. Intense rainfall events and rapid changes in temperature affected all five surveyed farm systems. Extreme high temperatures impacted the TC, IES and IS systems, while extreme low temperatures impacted the striped catfish groups (SCN and SCG). Striped catfish farming systems were more sensitive to low temperatures in comparison to shrimp and tilapia. For risk management purposes, increasing pond dike height was applied in the SCN and SCG farming systems. While increased pond depth was observed in the SCN, SCG and IS systems, the IS and SCN systems had higher counts of additional pond construction. Water quality was monitored and feed supplements/medicines were used by farmers in all five farm systems; however, these activities were higher for the SCN, SCG and IS systems than for the TC and IES groups. Reduced stocking density was observed in TC, SCN, SCG and IS, but not in IES. In addition, the use of aerators or mixers was the most-employed solution in the IS system. Amongst information sources of climate-related risks, television was found to be the most important, followed by neighbouring farmers and the Department of Fisheries (DOF). With regard to issues of high concern, the price of marketable size fish, diseases and feed and fingerlings were identified, as were the environmental parameters of rapid temperature change and high and low temperatures. 


\section{INTRODUCTION}

Climate change results in increase the frequency of droughts, hot weather, heavy rain, and highly variable rainfall patterns. Moreover, extreme weather conditions will increase in high latitudes and may decline in most subtropical regions (United States Environmental Protection Agency [USEPA], 2012). Drought and rising temperatures cause evaporation that reduces the amount of freshwater in rivers and bays, where it is affected by tides to increase salinity in estuarine areas (USEPA, 2012). It is estimated that by 2070 , the rainfall in Vietnam will increase $0-5 \%$ in the dry season and $0-10 \%$ in the rainy season (United Nations Framework Convention on Climate Change [UNFCCC], 2003). Specifically, in the Mekong Delta (MD), rainfall will decrease 10 $20 \%$ during the early rainy season and increase at the end of the rainy season (Tuan \& Suppakorn, 2011). As global temperatures have increased by $0.74^{\circ} \mathrm{C}$ from 1906 to 2005 and are expected to increase about $0.2^{\circ} \mathrm{C}$ per decade in the next 20 years (Intergovernmental Panel on Climate Change [IPCC], 2007), it is estimated that by 2050 and 2070, the average temperature of coastal and inland of $\mathrm{Vi}$ etnam will increase by $1.1^{\circ} \mathrm{C}$ to $1.5^{\circ} \mathrm{C}$ and $1.8^{\circ} \mathrm{C}$ to $2.5^{\circ} \mathrm{C}$, respectively (UNFCCC, 2003). In the MD, the highest temperature in the dry season will increase by $2^{\circ} \mathrm{C}$ (to $35-37^{\circ} \mathrm{C}$ ) in the period $2030-2040$ (Tuan \& Suppakorn, 2011). In addition, it is predicted that sea level will increase by $33 \mathrm{~cm}$ and 1.0 $\mathrm{m}$ by 2050 and 2100, respectively (UNFCCC, 2003). It is estimated that when the sea level rises up $40 \mathrm{~cm}$, about 20 million people in Southeast Asia will be affected by floods. Because most of the MD area has a topography $<2 \mathrm{~m}$ above sea level (Vietnam National University, 2019), this area is most affected by a rise in sea level (Nicholls, 2006). The flooded area will increase towards the Ca Mau peninsula, and the risk for the occurrence and landing of storms and tropical depressions will be higher by the end of the year (Tuan \& Suppakorn, 2011).

Vietnam's economy has ranked $27^{\text {th }}$ in terms of vulnerability to climate change impacts on the fisheries sector (Allison et al., 2009). In the MD, striped catfish (Pangasianodon hypophthalmus) and brackish shrimp (Penaeus monodon and Litopenaeus vannamei) are key species that contribute significantly to exported aquaculture production, and red tilapia (Oreochromis sp.) is used for domestic consumption. Together, owing to their positive economic impact, these aquaculture systems are improving the living standards of local people. The culture areas for striped catfish and red tilapia (cage culture) stretches from the upstream provinces to the areas adjacent to brackish water, while the area for shrimp occupies a large portion of the coastal provinces.

In striped catfish farming, salinity intrusion had reduced the scale of farms located in the downstream regions, and increased water salinity could in turn increase operational costs because of the need to have salinity-tolerant seed and prolong the culture period (Anh et al., 2018). Farmers in the brackish water aquaculture region (with black tiger shrimp culture in intensive, improved extensive and rotational rice - shrimp systems) had recognized more clearly the impact of climate change and salinity intrusion than farmers in the freshwater aquaculture region (with climbing perch, knife fish, snakeskin and rice-fish farming systems) (Mai, 2017). Almost all brackish water aquaculture farmers had thought that by applying advanced technologies such as the use of chemicals, aeration and water quality management, they could mitigate the negative impact of climate change and salinity issues on their farms; in contrast, farmers in the freshwater aquaculture region did not consider these issues at all. In Bangladesh, the vulnerability of aquaculture varies between different regions (inland and coastal) based on differences in climatic exposure, sensitivity and adaptive capacity of aquaculture farming (Islam et al., 2019). In order to conduct a comprehensive assessment of the issues mentioned above, this study aimed to determine the current status of climate change-related risks (CCRs) and their impact on farming systems and farmers' adaptive activities, and consequently to provide information helpful to mitigating negative impacts on aquaculture farming systems in the MD, Vietnam.

\section{METHODS}

\subsection{Data collection}

An in-depth, structured questionnaire survey was carried out from 25 January to 30 March 2018 with 601 farmers, using a clustered sampling method based on the different provinces and farming systems. The culture systems chosen for the study included striped catfish grow-out (SCG) (107), striped catfish nursery ( $\mathrm{SCN})(97)$, tilapia cage culture (TC) (198), intensive shrimp system (IS) (139) and improved extensive shrimp system (IES) (60) (Table 1). Site numbers refer to locations in Figure 1. 
Table 1. The locations and sample sizes of surveyed farmers

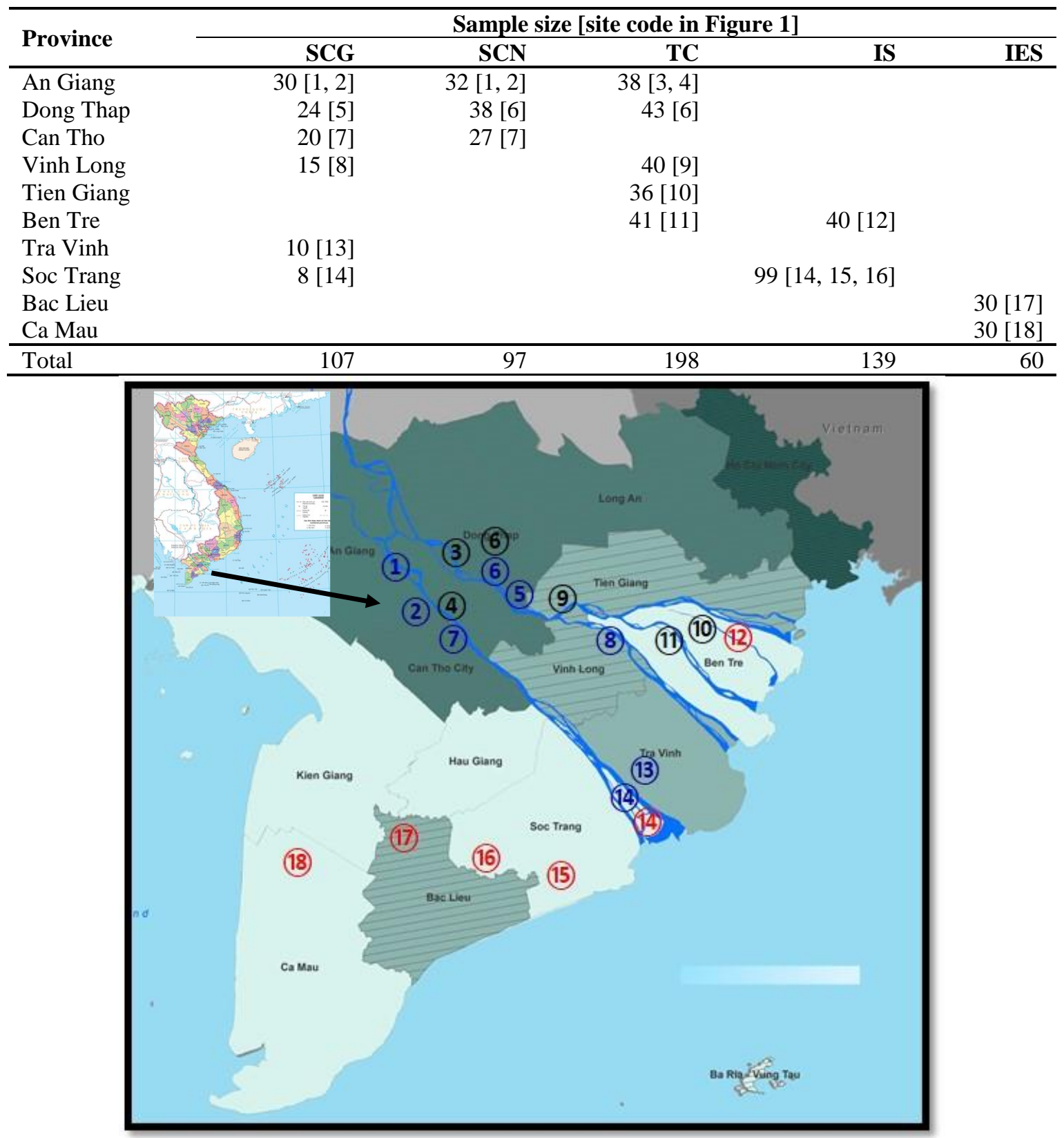

Figure 1. Location of sampling sites for in-depth survey in the MD, Vietnam 
Table 2. Questionnaire option selections by farmers and codes

\begin{tabular}{|c|c|}
\hline Variable & $\begin{array}{l}\text { Interval/or nominal/or ranking } \\
\text { [coded value] }\end{array}$ \\
\hline A. Background of farming systems & Interval/or nominal \\
\hline No. of pond/or cage & Number \\
\hline Size of pond/or cage & $\mathrm{m}^{2} /$ or $\mathrm{m}^{3}$ \\
\hline Stocking density & Ind. $/ \mathrm{m}^{2}$ of pond/or $\mathrm{m}^{3}$ of cage \\
\hline Yield & $\mathrm{kg} / 1,000 \mathrm{~m}^{2}$ of pond/or $\mathrm{m}^{3}$ of cage \\
\hline eFCR (economical feed conversion ratio) & Number \\
\hline Gender & Male [1], Female [2] \\
\hline Farming experiences (year) & $1-5[1], 6-10[2], 11-15[3],>15[4]$ \\
\hline Source of water supply & Irrigation [1], river [2] \\
\hline Pond used for storage water & Yes [1], No [0] \\
\hline B. CCR causes & Nominal \\
\hline $\begin{array}{l}\text { Floods or high flows, droughts or low flows, extreme } \\
\text { high temperature, extreme low temperature, rapid } \\
\text { changes in temperature, long periods with dense cloud } \\
\text { cover, intense rainfall events, storm surges }\end{array}$ & Yes [1], No [0] \\
\hline $\begin{array}{l}\text { C. Negative impacts of CCR causes on farming } \\
\text { systems }\end{array}$ & Nominal \\
\hline $\begin{array}{l}\text { High mortality of fish/shrimp, many fish escaped, } \\
\text { equipment damaged, low growth of fish/shrimp }\end{array}$ & Yes [1], No [0] \\
\hline $\begin{array}{l}\text { D. Issues concerning CCR causes related to the } \\
\text { profitability of farmers }\end{array}$ & Concerning ranking \\
\hline $\begin{array}{l}\text { Floods or high-flows, droughts or low-flows, extreme } \\
\text { high temperatures, extreme low temperatures, rapid } \\
\text { changes in temperature, long periods with dense cloud } \\
\text { cover, intense rainfall events, high wind storms }\end{array}$ & $\begin{array}{l}\text { Not concerned at all [1], Slightly concerned [2], } \\
\text { Somewhat Concerned [3], Moderately con- } \\
\text { cerned [4], Very concerned [5] }\end{array}$ \\
\hline
\end{tabular}

\begin{tabular}{ll}
\hline E. Responses of farmers against CCR causes & Nominal \\
\hline E.1. Modifying pond construction & \\
\hline $\begin{array}{l}\text { Lined ponds to better retain water, increased height of } \\
\text { dikes, made pond deeper, dug an additional pond }\end{array}$ & Yes [1], No [0] \\
\hline E.2. Techniques applied & Nominal \\
\hline $\begin{array}{l}\text { Monitored water quality, used aeration or mixers, har- } \\
\text { vested crop early, used feed supplements/medicines, } \\
\text { exchanged water, moved fish between sites }\end{array}$ & Yes [1], No [0] \\
\hline E.3. Adjusted techniques in the upcoming season & Nominal \\
\hline $\begin{array}{l}\text { Prepared or repaired aerators or mixers, reduced stock- } \\
\text { ing density, stocked larger fingerlings, delayed stock- } \\
\text { ing for a month or more, stored additional water, }\end{array}$ & \\
moved fish between sites &
\end{tabular}

\section{F. Important information sources to adapt to Importance ranking \\ CCR causes}

Farmers, Department of Fisheries (DOF), officials from local government, companies, group of farmers, $\mathrm{TV}$, Internet, radio, newspaper

\subsection{Data analysis}

The collected data were entered into Excel, and an exploratory activity was used to reject abnormal and outlier data before carrying out the analysing procedure. The different characteristics (importance and frequency) amongst surveyed farming systems were
Not at all important [1], Slightly important [2], Somewhat important [3], Important [4], Very important [5]

compared using non-parametric analysis of variance (ANOVA) (Kruskal-Wallis) and correlation (crosstable, chi-square) and chi-square automatic interaction detection (CHAID) methods (decision tree) $(\mathrm{p}<0.05)$ using SPSS 22.0. 


\section{RESULTS}

\subsection{Background information}

In general, the five farming systems have differences in technical characteristics such as pond size, stocking density, and yield because of the biological characteristics of the cultured species. In each farming system, there is a wide range of variation in the key technical characteristics due to different natural conditions and intensification levels of the farms (Table 3). All five farming systems have used hatchery seed and commercial pellet feed. In addition, the farmers of SCN also employed homemade feed as a supplementary diet for young fries at the beginning of the nursing period. In the SCN, farmers used fries to grow up fingerlings, with sizes of 30-50 fingerlings $/ \mathrm{kg}$ sold to grow-out farmers. In the IES, almost all shrimp farmers did not administer feed to their shrimp due to the plentiful amount of natural food available in the water bodies. Meanwhile, the majority of shrimp farmers stocked $\mathrm{PL}_{12}-\mathrm{PL}_{15}$, with a culture period of 3-5 months. The TC farmers used fingerlings at $25-50$ fishes $/ \mathrm{kg}$ for cage culture, and after 5-7 months of culturing, fish were harvested at sizes over $0.5 \mathrm{~kg} / \mathrm{fish}$.

Table 3. Major technical characteristics of the five farming systems

\begin{tabular}{lrrrrr}
\hline Items & TC & SCG & SCN & IS & IES \\
\hline $\begin{array}{l}\text { No. of pond } \\
\text { /or cage }\end{array}$ & $6 \pm 8$ & $3 \pm 3$ & $2 \pm 2$ & $3 \pm 2$ & $2 \pm 1$ \\
\hline $\begin{array}{l}\text { Size of pond }\left(\mathrm{m}^{2}\right) \\
\text { /or cage }\left(\mathrm{m}^{3}\right)\end{array}$ & $149 \pm 88$ & $5.442 \pm 9.658$ & $6.856 \pm 8.044$ & $2.704 \pm 1.914$ & $14.132 \pm 9.710$ \\
\hline $\begin{array}{l}\text { Stocking density } \\
\text { pond/or m } \text { of cage) }^{3}\end{array}$ & $191 \pm 122$ & $52 \pm 44$ & $811 \pm 347$ & $58 \pm 43$ & $10 \pm 25$ \\
\hline $\begin{array}{l}\text { Yield }\left(\mathrm{kg} / 1,000 \mathrm{~m}^{2} \text { of pond/or }\right. \\
\mathrm{m}^{3} \text { of cage) }\end{array}$ & $74.42 \pm 52.86$ & $31,260 \pm 18,610$ & $3,760 \pm 8,880$ & $1,970 \pm 5,720$ & $110 \pm 200$ \\
\hline eFCR & $1,82 \pm 0,47$ & $1,55 \pm 0,36$ & $1,20 \pm 0,51$ & $1,23 \pm 0,42$ & $0,26 \pm 0,48$ \\
\hline
\end{tabular}

Mean \pm standard deviation; eFCR: economical feed conversion ratio

The five farming systems are operated mainly by men who have more than 5 years of farming experience. Sources of water for ponds were mainly from irrigation and the main river. However, these farming systems had a low percentage of storage pond use: only $21.6 \%$ of IS farms, and not at all in TC or SCG systems. The low percentage of storage ponds for fish and shrimp culture resulted in a low capacity of water exchange (with good water quality) in the case of an emergency caused by CCRs or fish disease; thus, these farming systems are highly dependent on the weather and environmental conditions in river or irrigation systems. As shown in Figure 2, there was a correlation between different farming systems (TC, SCN, SCG, IS and IES) with regard to gender, farmers' experience and irrigation canal, river and storage pond water use $(\mathrm{p}<0.05)$.

Farmer's gender: Farmer's gender showed both women and men functioning as owner and management. However, men dominated women in all five farming systems. The percentage of female ownership of TC (20.7\%) and IS (27.3\%) systems was higher than that for SCN (8.2\%), SCG (13.1\%) and IES $(6.7 \%)$ systems $(\mathrm{p}<0.05)$.
Farming experience: most farmers of the five farming systems had more than 5 years of experience. Farmers with 6-10 years of experience were highest in the TC (42.4\%) and SCN (37.1\%) systems. In the SCG farmer group, most (42.1\%) had 11-15 years of experience. In the IES and IS farmer groups, farming experience of more than 15 years was $48.3 \%$ and $29.5 \%$, respectively. This result shows that shrimp farming has had a longer history than striped catfish farming in the MD.

Irrigation system: many SCN farmers used freshwater from irrigation (63.9\%) and river systems $(63.9 \%)$. However, the SCG (82.2\%), IS (66.2\%) and IES $(66.7 \%)$ systems used water from the river. Most TC farms were located in the main flow of the Mekong River; however, some TC farms had nursing ponds and used irrigation canals for their water supply.

Pond used for storage water: a small percentage of farmers engaged in the SCN, IS and IES groups used water storage ponds to supply water into culture ponds $-1.0 \%, 21.6 \%$ and $1.7 \%$, respectively. 


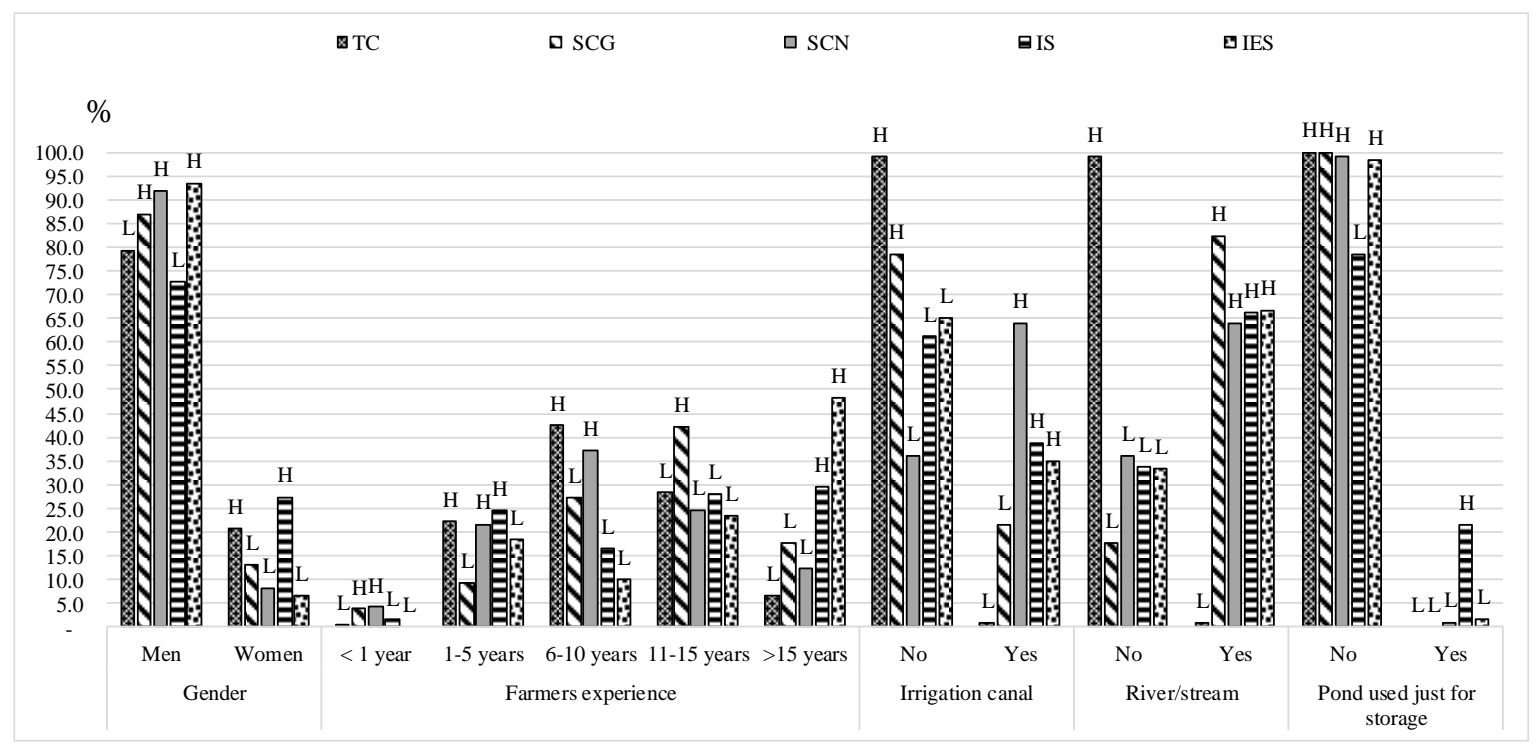

Figure 2. Farmer's background and water inlet characteristics

(Values are in percentages (\%), Chi-square test for relationships of different farming systems (row) crossing with farmer's background parameters (column). Cross table-Chi-square. H/L: significant higher/lower expected percentage, $p<0.05$ ).

\subsection{Impact of CCR on farming systems}

Rainfall and temperature issues: intense rainfall events (Yes answer for TC: $16.2 \%$; SCN: 79.4\%; SCG: $48.6 \%$; IES: $43.3 \%$; and IS: $42.4 \%$ ) and rapid changes in temperature (Yes answer for TC: $18.2 \%$; SCN: $43.3 \%$; SCG: $31.8 \%$; IES: $36.7 \%$; and IS: $38.1 \%$ ) were the main three causes that affected the five farming systems. Meanwhile, extreme high temperatures greatly affected the TC (35.9\%), IES $(31.7 \%)$ and IS (28.8\%) systems; and extreme low temperatures was a serious issue for the striped catfish group (SCN: 54.6\%; and SCG: 54.2\%). Results indicated that the striped catfish were more sensitive to low temperatures compared to shrimp and tilapia.

Flood issue: floods or high flows caused more serious problems for the TC, SCN and SCG groups (affected by flooding water from the Mekong River) compared to the brackish water farming systems located in the coastal areas (IES and IS). For farms located in the Mekong River, low flows impacted the TC system more than the SCN, SCG, IES and IS systems. In the dry season, low flows result in shallow water in upstream provinces (e.g. An Giang and
Dong Thap provinces) and the risk of salinity intrusion into downstream provinces (e.g. Ben Tre and Tra Vinh provinces).

Temperature issue: extreme high temperatures were of greatest concern for the TC (cause of bacterial disease occurrence) and IES (shallow pond) systems than for the other three remaining farming systems. Rapid changes in temperature and intense rainfall events greatly affect the TC group because this farming system is based in rivers with huge water body volumes. Meanwhile, the SCN, SCG, IES, and IS systems are more sensitive to intense rainfall and temperature change due to a wide range of salinity and temperature fluctuations.

Extreme low temperatures and long periods of cloudiness impact the SCN and SCG systems the most because such events lead to parasitic diseases in striped catfish. Storm surges highly affect the TC and IS groups, as they are typically located in large rivers and coastal areas, respectively, which have greater vulnerability to changing weather. 


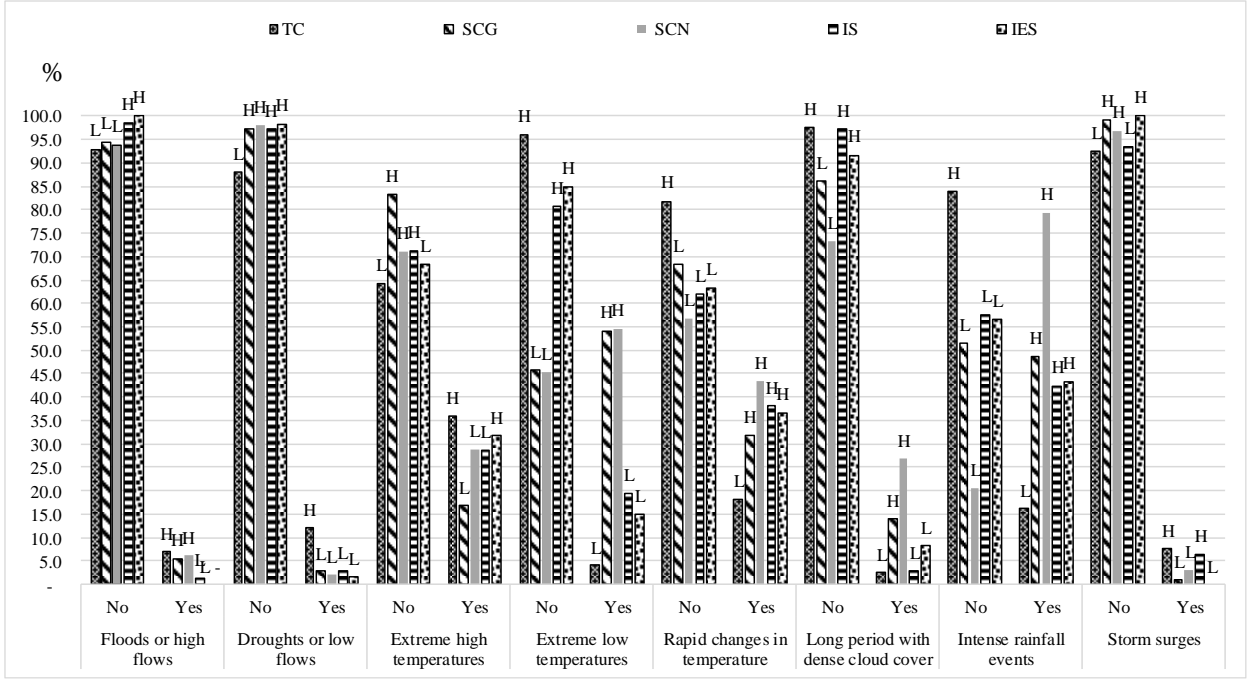

Figure 3. Negative impact of CCRs in the five farming systems

(Values are in percentages (\%), Chi-square test for relationships of different farming systems (row) crossing with farmer's background parameters (column). Cross table - Chi-square. H/L: significant higher/lower expected percentage, $p<0.05$ )

Suffered production issue: the survey results showed that due to the negative impact of CCRs, a high percentage of farmers suffered losses such as 'high mortality of fish/shrimp' and 'slow growth' in all five farming systems (>89.9\% and $>30.9 \%$, respectively), while other losses of 'many fish escaped' and 'equipment damaged' had low percentages $(<6.1 \%$ and $<7.2 \%$, respectively). Fish and shrimp crop damaged by 'high mortality of fish/shrimp' in the SCG, IS and IES groups had a higher percentage $(p<0.05)$ compared to that of the
TC and SCN groups. Losses attributable to 'low growth of fish/shrimp' in the TC and SCN systems were higher than in the other systems $(\mathrm{p}<0.05)$. Although a low percentage of farmers answered that 'many fish escaped' in all farming systems, due to tilapia cultured in cage and nursing ponds closed to river inflow, the TC system had a high percentage of losses of 'many fish escaped' compared to that of the SCG, SCN, IS and IES systems $(\mathrm{p}<0.05)$ (Figure 4).

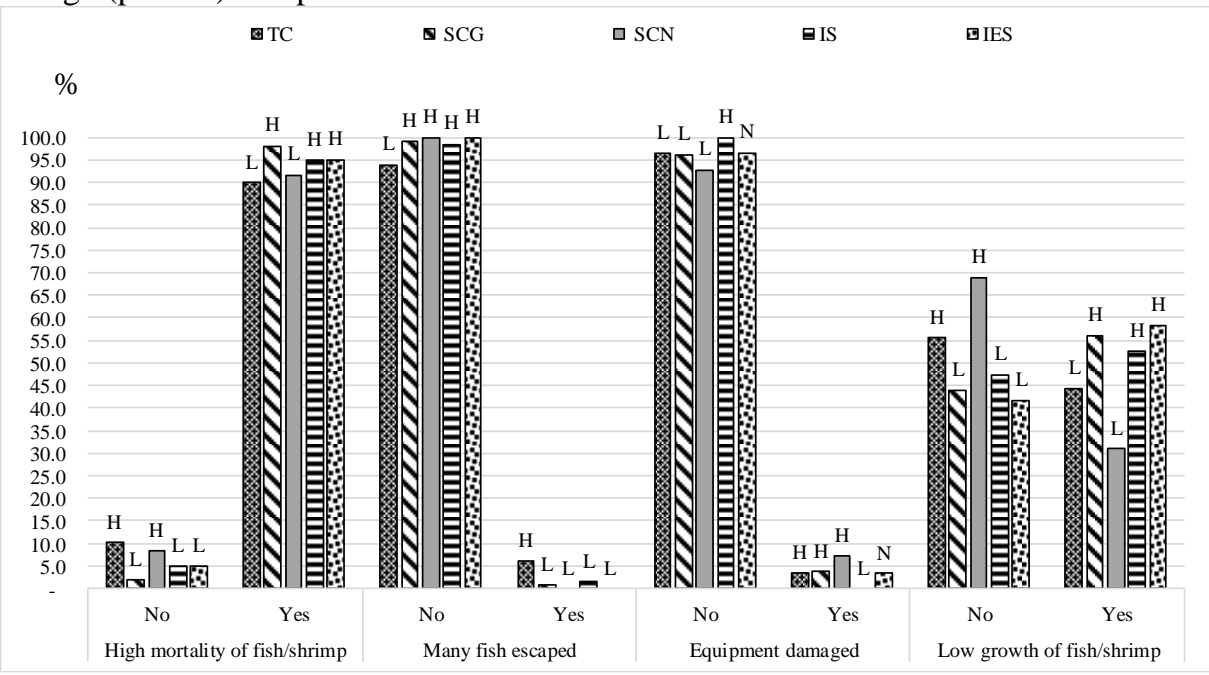

Figure 4. Crop damaged by negative impact of CCRs in the five farming systems

(Values are in percentages (\%), Chi-square test for relationships of different farming systems (row) crossing with farmer's background parameters (column). Cross table-Chi-square. H/L: significant higher/lower expected percentage $(p<0.05)$. $N$ : no expected residue frequency) 


\subsection{Impact of CCRs on the profitability of farming systems}

Results indicated that the concerned level differences of CCRs and other risks from the surrounding environment was higher than 2.5 (ranked from 1: not concerned at all, to 5: very concerned); effects on the profit of farms are identified in Table 3. There were no significant differences in levels of concern to climate-related risk between the five culture systems $(p>0.05)$. However, the highest concerned score effect on the profit of the TC farm belonged to 'extreme high temperatures' (with suitable conditions for the development of bacterial diseases), followed by 'extreme low temperature' in SCG farms (causing parasitic diseases). SCN farms had problems in 'intense rainfall events' (causing fluctuation of water quality because of shallow water depth); meanwhile, IS and IES farms were affected by 'rapid changes in temperature' (causing viral dis- eases). These CCR impacts may result in poor survival rates and yield, and in higher costs for fish/shrimp health management.

With regard to the other risks affecting the profit of fish and shrimp farms, 'spread of fish/shrimp diseases' was ranked at the highest level of concern, but the difference was not found to be significant $(p<0.05)$. Meanwhile, "pollution from other activities' was at the highest level of concern in SCPSCG farms compared to the TC, IS, IES and SCG farms, significantly $(\mathrm{p}<0.05)$; and 'low dissolved oxygen' was at the highest level of concern in the SCG and IS farms compared to the TC, IES and SCN farms, significantly $(\mathrm{p}<0.05)$. These differences are due to the SCG and IS farms having high stocking densities, leading to higher risks of low dissolved oxygen and water pollution compared to the TC, IES and SCN

systems

Table 4. Concerning levels of CCRs and other risks to the profitability of fish farm

\begin{tabular}{lccccc}
\hline Impact & TC & SCG & IS & IES & SCN \\
\hline $\boldsymbol{C C R} \boldsymbol{s}$ & & & & & \\
\hline Floods or high-flows & $2.9 \pm 1.1$ & $3.2 \pm 0.9$ & $2.9 \pm 0.8$ & $2.8 \pm 0.8$ & $3.0 \pm 1.1$ \\
Droughts or low-flows & $3.3 \pm 1.1$ & $2.7 \pm 1.0$ & $3.3 \pm 1.0$ & $3.2 \pm 1.0$ & $2.6 \pm 1.3$ \\
Extreme high temperatures & $3.8 \pm 1.1$ & $2.6 \pm 1.3$ & $3.9 \pm 1.0$ & $\mathbf{4 . 2} \pm \mathbf{1 . 0}$ & $2.8 \pm 1.3$ \\
Extreme low temperatures & $2.8 \pm 1.1$ & $\mathbf{4 . 3} \pm \mathbf{1 . 0}$ & $3.9 \pm 0.9$ & $4.0 \pm 0.9$ & $4.0 \pm 1.0$ \\
Rapid changes in temperature & $3.4 \pm 1.1$ & $3.9 \pm 0.9$ & $\mathbf{4 . 2} \pm \mathbf{0 . 8}$ & $\mathbf{4 . 4} \pm \mathbf{0 . 6}$ & $4.0 \pm 0.6$ \\
Long periods with dense cloud cover & $2.6 \pm 0.9$ & $3.3 \pm 1.0$ & $3.1 \pm 0.9$ & $3.3 \pm 0.8$ & $3.7 \pm 0.9$ \\
Intense rainfall events & $3.2 \pm 1.1$ & $4.1 \pm 0.8$ & $4.1 \pm 0.9$ & $4.1 \pm 0.9$ & $\mathbf{4 . 3} \pm \mathbf{0 . 7}$ \\
High wind storms & $3.5 \pm 1.0$ & $3.6 \pm 0.8$ & $3.9 \pm 0.8$ & $3.8 \pm 0.9$ & $3.5 \pm 1.1$ \\
\hline Other risks caused by CCRs or the surrounding environment & & & \\
\hline Spread of fish diseases & $4.0 \pm 0.7$ & $4.2 \pm 0.6$ & $4.2 \pm 0.5$ & $4.1 \pm 0.4$ & $4.1 \pm 0.7$ \\
Pollution from other activities & $3.4 \pm 0.9^{\mathrm{a}}$ & $\mathbf{4 . 0}^{\mathrm{n}} \pm \mathbf{1 . 1} \mathbf{1}^{\mathbf{b}}$ & $3.5 \pm 1.0^{\mathrm{a}}$ & $3.5 \pm 1.0^{\mathrm{a}}$ & $3.2 \pm 1.1^{\mathrm{a}}$ \\
Low dissolved oxygen & $2.8 \pm 1.0^{\mathrm{a}}$ & $\mathbf{3 . 2} \pm \mathbf{1 . 0}^{\mathbf{b}}$ & $\mathbf{3 . 2} \pm \mathbf{0 . 8}$ & $3.1 \pm 0.8^{\mathrm{ab}}$ & $2.8 \pm 1.1^{\mathrm{a}}$ \\
\hline
\end{tabular}

Ranking value coded as 1: not concerned at all; 2 : slightly concerned; 3: somewhat concerned; 4 : concerned; 5: very concerned (Mean \pm Std. dev.). Means with the same superscript letters represent non-significant difference, Kruskal-Wallis test $(p<0.05)$.

\subsection{Responses of farmers to negative impacts of CCRs}

\subsubsection{Enhancing pond construction}

Enhancing pond construction is one of the main responses to reduce the negative impacts of CCR; the percentage of farmers increasing pond dyke height in the SCN and SCG systems is $11.3 \%$ and $24.3 \%$, respectively. In addition, increasing the depth of ponds for the SCN, SCG and IS groups was $15.5 \%$, $11.2 \%$ and $7.2 \%$, respectively; and digging additional ponds by the IS farmer was $5.8 \%$. Most TC farmers showed no response in enhancing pond construction due to the in-river location of fish cages (although very few farms had fingerling nursing ponds); the relationships between the responses of farmers and farming systems $(p<0.05)$ are shown in Figure 5. Increasing the height of pond dykes in the SCN and SCG systems was higher than that of other farming systems $(\mathrm{p}<0.05)$, while increasing the water depth of ponds/cages was the response of the SCN, SCG and IS systems, which was of a higher frequency compared to that of the TC and IES groups $(\mathrm{p}<0.05)$. The IS and SCN systems had higher percentages of digging additional ponds, since they had stocked at higher densities compared to the TC, SCG and IES systems $(\mathrm{p}<0.05)$ (Figure 5). 


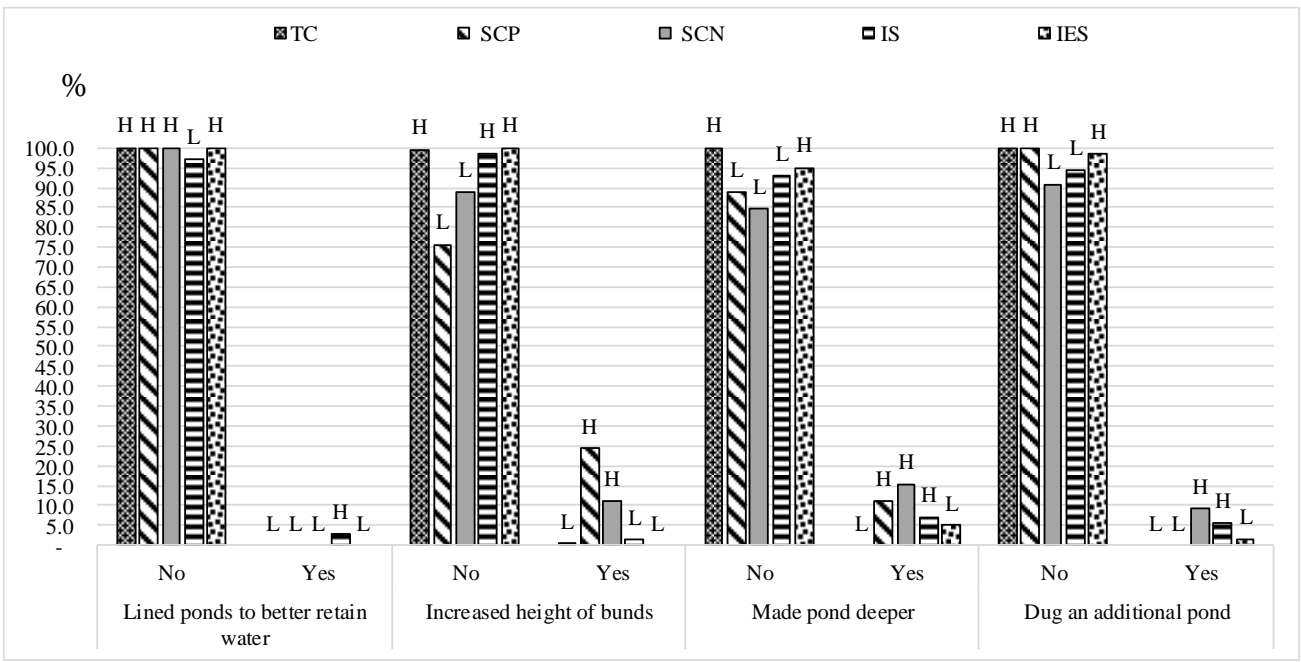

Figure 5. Response of farmers to CCR causes by enhancing pond construction

(Values are in percentages (\%), Chi-square test for relationships of different farming systems (row) crossing with farmer's background parameters (column); cross table - Chi-square, H/L: significant higher/lower expected percentage, $p<0.05)$. H/L: significant higher/lower expected frequency ( $p<0.05)$; $N$ : no expected residue frequency)

\subsubsection{Improving current farm management practices}

Immediately eliminating the negative impact of CCRs: to maintain water quality in the face of CCR impacts during fish/shrimp pond operation, farmers had to act immediately to improve the health of the fish/shrimp. Monitoring water quality and using feed with supplements/medicines were the main responses of the farmers in the five farming systems.
However, these measures were adopted in a particularly higher manner by the SCN, SCG and IS groups than by the TC and IES groups $(\mathrm{p}<0.05)$. Water exchange was another frequently implemented measure, with a high frequency of use by the SCN $(43.3 \%)$, SCG $(61.7 \%)$ and IES $(27.1 \%)$ systems compared to the IS system $(\mathrm{p}<0.05)$. Farmers of the IS system had the highest percentage $(85.6 \%)$ of using aerators or mixers to improve water quality due to high stocking density (Figure 6).

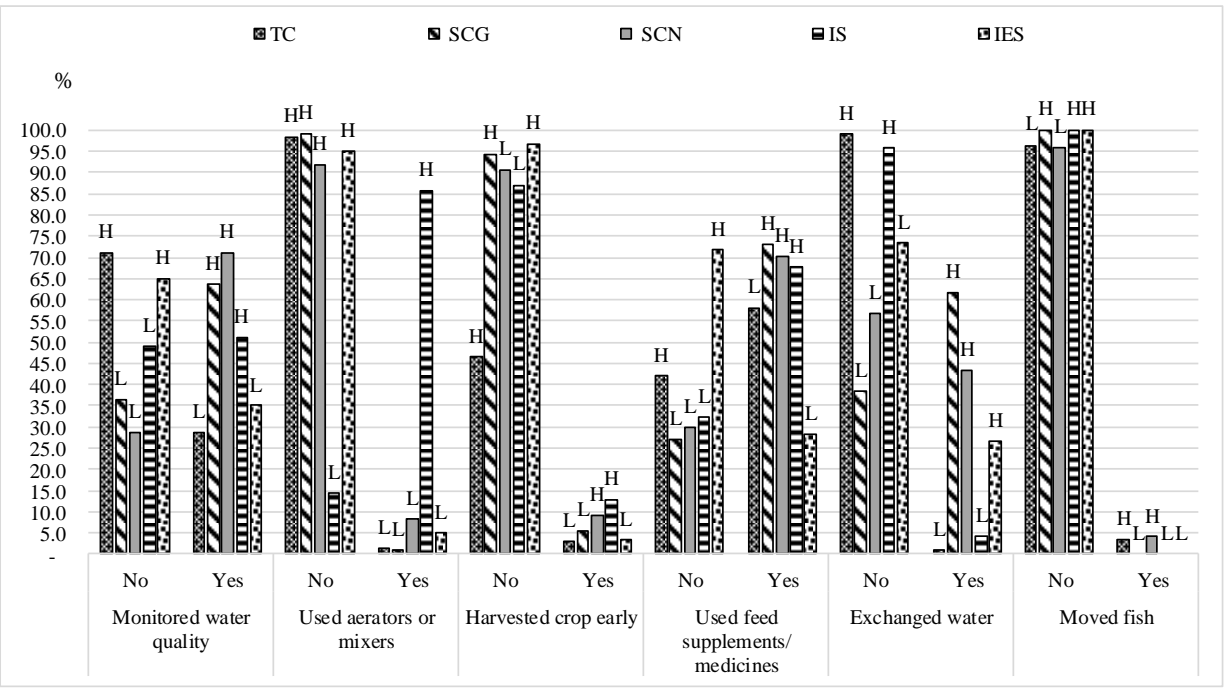

Figure 6. Responses of farmers to immediately reduce CCR impacts

(Values are in percentages (\%), Chi-square test for relationship of different farming systems (row) crossing with farmer's background parameters (column); cross table - Chi-square, H/L: significant higher/lower expected percentage, $p<0.05)$. H/L: significant higher/lower expected frequency, $p<0.05)$. 


\subsubsection{Activities to reduce risks in the coming seasons}

With regard to upcoming responses, reducing stocking density will be employed by farmers in four systems: TC (30.3\%), SCN (60.8\%), SCG (34.6\%) and IS $(33.8 \%)$. In aquaculture, farms that apply a high stocking density could cause poor water quality and thus affect the health of fish and shrimp. For these reasons, farmers in the four systems have to more significantly engage in intensive actions to care for fish/shrimp than the IES system would $(0 \%)$ $(p<0.05)$. Around one-half $(49.6 \%)$ of farmers in the
IS system would employ aerators or mixers for ponds, which is significantly greater than that of the TC, SCN, SCG and IES systems $(\mathrm{p}<0.05)$. In particular, 'prepared or repaired aerators or mixers' and 'reduced stocking density' will be the solutions of many farmers, especially in the IS system. Given the percentages of response for the four groups (TC, SCN, SCG and IS), the highest percentage of stocking density reduction will be carried out by SCG and SCN farmers, as they have been employing high stocking densities when compared to the remaining farm systems (Figure 7).

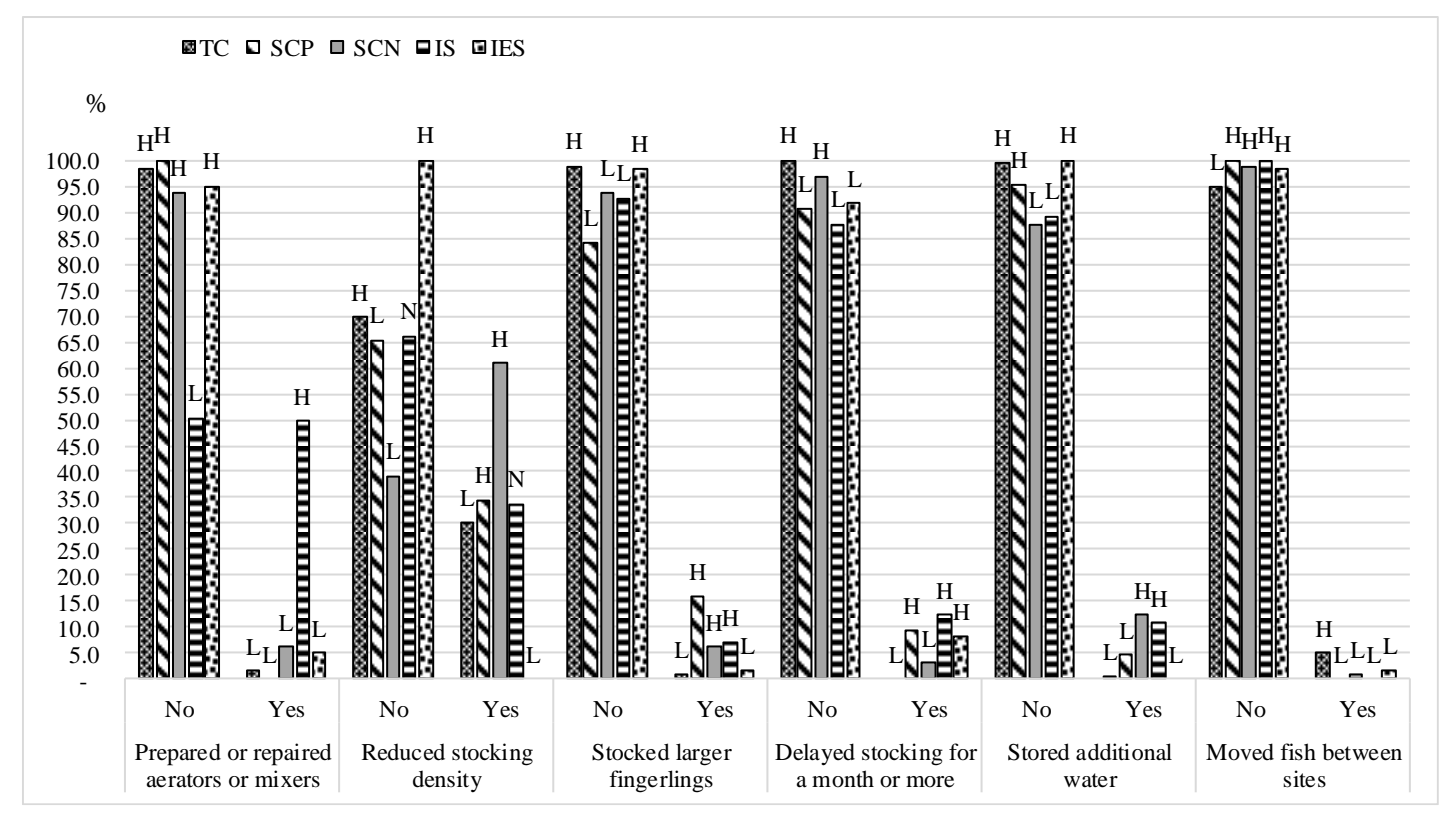

Figure 7. Measurements of farmer responses to reduce CCR impacts in upcoming seasons

(Values are in percentages (\%), Chi-square test for relationships of different farming systems (row) crossing with farmer's background parameters (column); cross table - Chi-square, H/L: significant higher/lower expected percentage, $p<0.05)$. H/L: significant higher/lower expected frequency, $p<0.05)$.

\subsubsection{Relationship between farmer's responses to CCR impacts and farming systems}

The immediate response of farmers to the negative impacts of CCRs is water quality monitoring ('monitored water quality' option selected). Weather conditions affect fish and shrimp by creating unfavourable water quality parameters such as water temperature, dissolved oxygen, $\mathrm{pH}$ and salinity fluctuation; therefore, monitoring water quality is an important immediate action taken by farmers in managing fish and shrimp ponds. In general, many farmers (47.6\%) applied 'monitored water quality'; of this number, $32.6 \%$ did not think about 'rapid changes in temperatures'. In farmer groups that had thought about 'rapid changes in temperature', the frequency of water quality monitoring differed amongst the five farming systems. First, the relationship between the five farming systems with regard to applying 'monitored water quality' is shown in Node 1 to 3, 4 and 5; data indicate that the SCN and SCG farmers display a high percentage of applying water quality monitoring (60.2\%). Because SCN and SCG farmers take river/canal water directly to the fish pond, without a settlement/treatment pond (to improve water quality of inlet water), and even though the SCN and SCG groups employed daily water exchange, farmers still monitored water quality for certainty. Meanwhile, the percentage for the IS group was $36.0 \%$, and it was $13.5 \%$ for both the TC 
and IES groups. Second (Node 3 to 8, 9), 80.3\% of SCN and SCG farmers who applied 'exchange water' had higher percentages of water quality monitoring $(80.3 \%)$ compared to that of the without 'water exchanged' farmer group. Third (Node 4 to 10, 11,12 ), in the TC and IES systems, farmers will employ 'optimising the stocking density' as their risk management strategy. In this group, $33.9 \%$ of farmers who considered adjusting stocking density in the range of 2 (slightly important) to 3 (somewhat important) had 'monitored water quality', which is higher than that of the remaining farmer groups. In contrast, $80.7 \%$ of the farmers who considered rapid changes in temperatures' as one of the CCRs applied 'water quality monitoring' as a tool to reduce the impact of CCRs, although there were no percentage differences in applying water quality monitoring amongst the five farming systems (Figure 8).

Figure 9 demonstrates that the immediate response of 'used aerators or mixers' could be divided into 3 groups, in which almost all IS farmers used aerators to improve the water quality of ponds $(85.6 \%)$, followed by SCN and IES farmers $(7.0 \%)$ and SCG farmers (1.3\%) (Node 0 to 3, 1 and 2). The percentage of IS farmers will employ 'repaired aerators or mixers' to reduce the negative impact of CCRs is 97.1\% (Node 3 to 9 ).

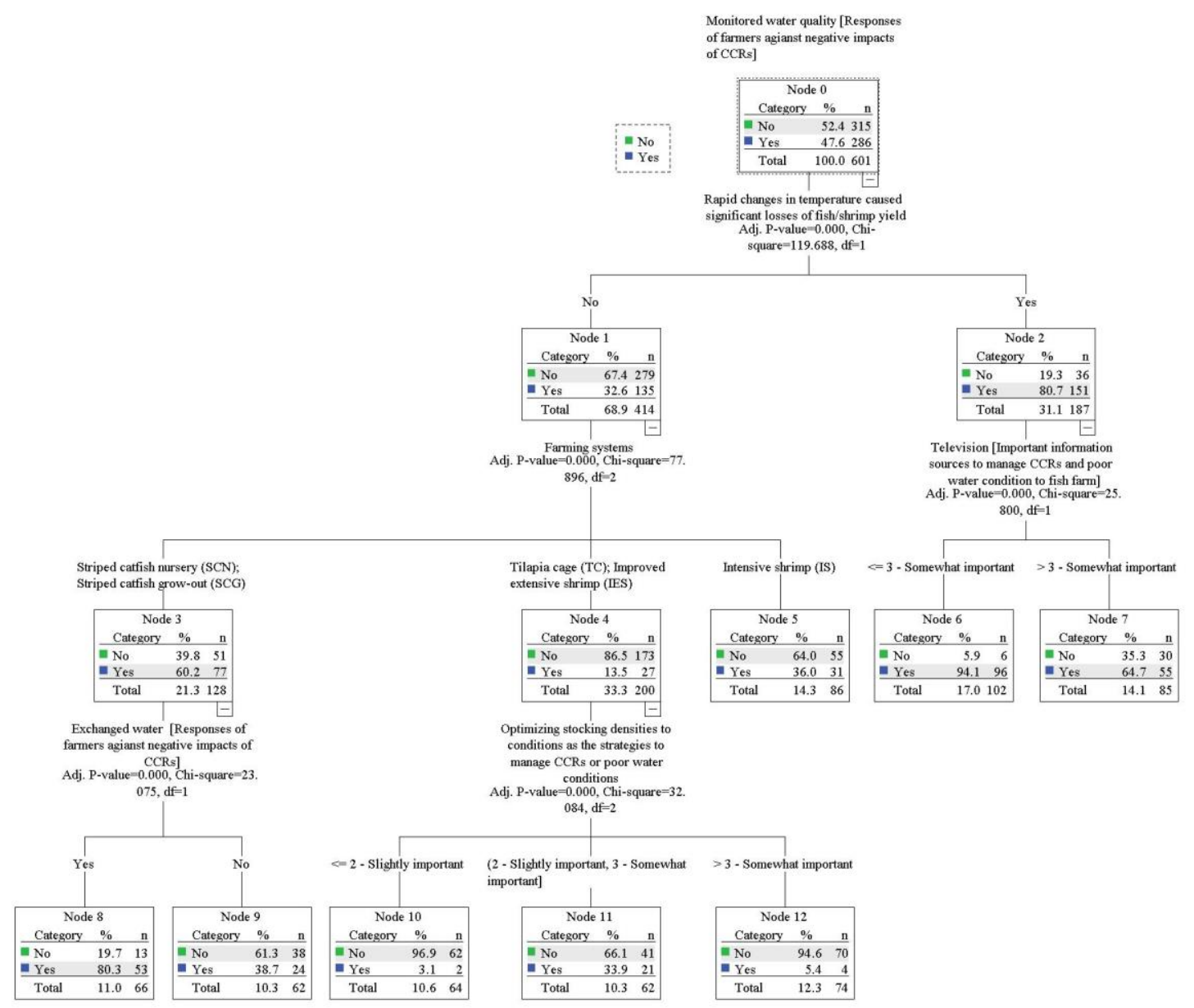

Figure 8. 'Monitored water quality' activities as an immediate response to CCRs 


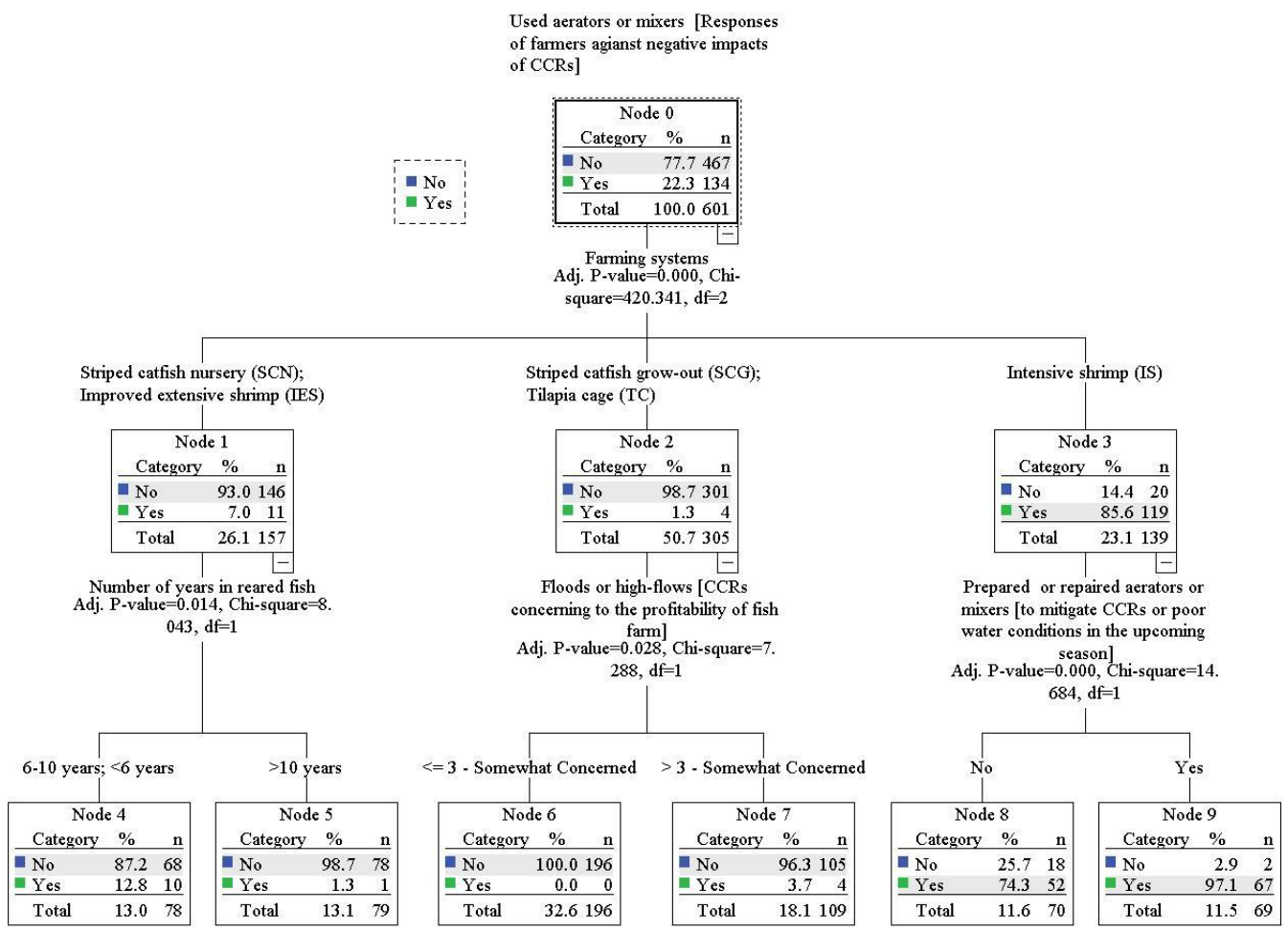

Figure 9. 'Used aerators or mixers' activities as an immediate response to CCRs

\subsection{Information sources and future activities to eliminate CCRs}

Important sources of information related to climate, weather and water conditions ranked by farmers of the five surveyed systems (TC, SCN, SCG, IES and IS) are shown in Table 5. First, television (TV) received the highest score as an information source, both now and for upcoming seasons; of note, SCG farmers thought that the information from TV was very important. Second was the helpful information from neighbouring farmers; TC farmers significantly ranked this source as being of lowest importance compared to SCN, SCG, IES and IS farmers $(p<0.05)$. Officials from the Department of Fisheries (DOF) were the third most important sources of information, especially for SCG farmers. Almost all sources of information were ranked at a low level of importance by TC and IES farmers, which indicates that the TC and IES farmers have no strong relationships with the mentioned organisations during their farming activities (Table 5).

Table 5. Important sources of CCR information expected by farmers

\begin{tabular}{|c|c|c|c|c|c|}
\hline Information source & TC & SCN & SCG & IS & IES \\
\hline Other fish farmers & $3.2 \pm 0.9^{a}$ & $3.7 \pm 0.8^{b}$ & $3.6 \pm 1.1^{b}$ & $3.7 \pm 0.8^{b}$ & $3.6 \pm 0.9^{b}$ \\
\hline Officials from Department of Fisheries & $2.7 \pm 0.7^{\mathrm{a}}$ & $2.9 \pm 0.9^{\mathrm{a}}$ & $3.2 \pm 0.8^{\mathrm{b}}$ & $3.2 \pm 0.7^{\mathrm{b}}$ & $2.6 \pm 0.6^{\mathrm{a}}$ \\
\hline Officials from local government & $2.6 \pm 0.9^{\mathrm{a}}$ & $2.8 \pm 0.8^{\mathrm{ab}}$ & $2.9 \pm 0.9^{b}$ & $3.3 \pm 0.8^{\mathrm{c}}$ & $2.8 \pm 0.7^{\mathrm{ab}}$ \\
\hline Agents from private companies & $2.3 \pm 1.0^{\mathrm{b}}$ & $2.3 \pm 1.1^{\mathrm{b}}$ & $2.7 \pm 1.1^{\mathrm{c}}$ & $2.4 \pm 1.1^{\mathrm{bc}}$ & $1.4 \pm 0.6^{\mathrm{a}}$ \\
\hline Bank or savings group & $1.7 \pm 0.8$ & $1.7 \pm 1.0$ & $1.8 \pm 0.8$ & $1.5 \pm 0.5$ & $1.4 \pm 0.5$ \\
\hline Television & $3.8 \pm 1.1^{\mathrm{a}}$ & $3.8 \pm 1.0^{\mathrm{a}}$ & $4.1 \pm 1.1^{b}$ & $3.7 \pm 1.0^{\mathrm{a}}$ & $3.8 \pm 1.1^{\mathrm{a}}$ \\
\hline Internet & $2.2 \pm 1.1^{\mathrm{a}}$ & $2.8 \pm 1.1^{\mathrm{b}}$ & $2.8 \pm 1.3^{\mathrm{b}}$ & $2.2 \pm 1.1^{\mathrm{a}}$ & $1.9 \pm 1.1^{\mathrm{a}}$ \\
\hline Radio & $1.7 \pm 1.0^{\mathrm{a}}$ & $2.6 \pm 1.1^{\mathrm{c}}$ & $2.1 \pm 1.0^{\mathrm{b}}$ & $2.2 \pm 1.1^{\mathrm{b}}$ & $2.1 \pm 0.9^{\mathrm{b}}$ \\
\hline Magazines or newspapers & $1.4 \pm 0.7^{\mathrm{a}}$ & $1.8 \pm 1.1^{\mathrm{b}}$ & $1.6 \pm 0.9^{\mathrm{b}}$ & $1.7 \pm 0.8^{\mathrm{b}}$ & $1.6 \pm 0.6^{\mathrm{b}}$ \\
\hline
\end{tabular}

Ranking value coded as 1: not at all important; 2: slightly important; 3: somewhat important; 4: important; 5: very important (Mean \pm Std. dev.). Means in the same row with the same superscript letters represent non-significant difference, Kruskal-Wallis test $(p<0.05))$. 


\section{DISCUSSION}

According to Mai et al. (2016a), almost all IES farmers (92-99\%) recognized the negative impact of climate change on their farms. Meanwhile, for snakeskin gourami (Trichogaster pectoralis), 59$84 \%$ of farmers considered heavy rainfall and temperature fluctuations as CCRs (Mai et al., 2016b). Almost all farmers (90\%) in rotational black tiger shrimp rice farming were aware of the negative impact of CCRs. The farmers' selected solution of techniques (using medicines/and shifting cropping calendar; 70.1-95.5\%) was greater than the others for dealing with changes related to the rainy season, rainfall, low and high temperature, low and high salinity, and low tide. To reduce the negative impact of low salinity, shifting the cropping calendar resulted in higher shrimp yields and net income $(0.5$ ton/ha/crop, 52.5 million VND/ha/crop) compared to that of the other farmer groups (Mai et al., 2015).

In the IES farmer group, $70-90 \%$ of farmers had used drugs and/or chemicals as technical solutions to managing water quality and shrimp health; this is the same as the technical solution of farmers in the snakeskin gourami culture (Mai et al., 2016a). In this study, the farmers have applied monitoring water quality, the use of supplements/chemical drugs and water exchange as important activities in all farming systems. In addition, the IS system has a high percentage of farmers employing aeration and harvesting crops early. In the coming season, farmers in these systems will choose the best solution for reducing stocking density in order to adapt to CCRs (except IES), while the IS model continues to employ 'prepared or repaired aerations or mixers' (33.8\%), 'delayed stocking time' $(12.2 \%)$ and stored additional water $(10.8 \%)$. In addition, farmers also appreciated the solution to choose better seeds and feed combined with working with other groups of farmers to secure better responses to CCRs. These current or upcoming responses of farmers are technical solutions that are dependent on technical skills/cost investments, and these expected solutions may be cost consuming and thereby reduce the benefit of shrimp and fish farming. To overcome the CCRs, the farmers need more assistance from government/non-government agencies to re-enforce farm construction and to improve adaptive technical skills. Also, the government should release a CCR forecast for specific farming systems and provide crop insurance to reduce the negative impact of CCRs (Soto et al., 2018).
Impacts of CCRs on aquaculture could be positive or negative, arising from direct and indirect impacts on water, land, seed, feed and energy. The negative impacts of CCRs would not only affect productivity, but also increase vulnerability to diseases and reduce net income to farmers (Food and Agriculture Organization of United Nations [FAO], 2008). In the SCG system, farmers in the upstream and midstream regions had larger scales of operation, whereas salinity intrusion reduced the scale of downstream farms. Also in the SCG system, an adaptation strategy requires a greater investment in better pond construction and having seed with salinity-tolerant characteristics as well as a larger seed size for grow-out farming systems (Anh et al., 2018). According to FAO (2008), to respond to salinity intrusion, farmers need to shift culture stenohaline species upstream or introduce marine or euryhaline species. With regard to issues of water stress and drought conditions, aquaculture farming systems should focus on the efficacy of water usage, low water consumption techniques and faster growing fish species. Moreover, advanced technologies for aquaculture need to be developed, include genetic improvements for more efficient feeding, increasing species resistance to higher temperatures, lower oxygen and pathogen-resistant seeds.

However, climate change may create new opportunities to diversify more resilient aquaculture-based livelihoods. In the coastal region of Bangladesh, waterlogged croplands are being transformed into crop-aquaculture systems for supplying food and income during post-disaster periods. Additionally, where rainfall can be erratic and with the flooding of wetlands, cage culture has been proposed as a means of producing fish during the dry season (Baranges et al., 2018). In Vietnam, salt-tolerant varieties of rice and rice-fish cultivation can reduce vulnerability to sea level rise and storm surge damage (Shelton, 2014). In the drought-prone regions of Africa, integrated agri-aquaculture production systems have been used to promote water-saving activities (Crespi \& Lovatelli, 2011). The introduction of cage-cultured tilapia in reservoirs provides alternative livelihoods and employment opportunities in Brazil to mitigate the negative impact of droughts and erratic rainfall (Soto et al., 2018). According to Soto et al. (2018), in the future, it may be difficult to foresee the negative impacts of climate change on aquaculture farming systems, but to mitigate the negative impact of climate change, aquaculture farming systems should be modified to reduce their 
sensitivity to such change, and measures to minimise the exposures of these farming systems to climate change impacts should be increased.

\section{CONCLUSIONS}

Intense rainfall events and rapid changes in temperatures highly affect TC, SCN, SCG, IES, and IS farming systems in the MD, Vietnam. Striped catfish farming is more sensitive to low temperatures compared to shrimp and tilapia. The percentage of increased height of pond dykes as a response to CCR impact in the SCN and SCG systems is higher compared to the IS and IES systems. Increasing pond depth, digging additional ponds, monitoring water quality and using feed supplements/medicines are commonly implemented responses in all five systems, but is noticeably greatest in intensive pond systems (SCN, SCG and IS). Reducing stocking density is also implemented in the TC, SCN, SCG and IS systems.

\section{ACKNOWLEDGMENT}

This study was supported by a grant (No. 108526) from the International Development Research Centre, Ottawa, Canada. The author also sincerely thanks the staff of DOF and farmers in Can Tho city, and Soc Trang, Ca Mau, Bac Lieu, Tra Vinh, Ben Tre, Tien Giang, Dong Thap, Vinh Long, and An Giang provinces for their participation and support of the research team to complete this study.

\section{REFERENCES}

Allison, E.H., Perry, A.L., Badjeck, M.C., Adger, W.N., Brown, K., Conway, D., Halls, A.S., Reynolds, J.D., Andrew, N.L. \& Dulvy, N.K. (2009). Vulnerability of national economies to the impacts of climate change on fisheries. Journal Compilation Fish and Fisheries, 10(2): 173-196.

Anh N.L., Tung B.V.P., Bosma R., Verreth J., Leemans R., De Silva S., \& Lansink, A.O. (2018). Impact of climate change on the technical efficiency of striped catfish, Pangasianodon hypophthalmus, farming in the Mekong Delta, Vietnam. Journal of the World Aquaculture Society, 49(3): 570-581.

Crespi, V., \& Lovatelli, A. (2011). Aquaculture in desert and arid lands: Development constraints and opportunities. FAO Technical Workshop, 6-9 July 2010, Hermosillo, Mexico. FAO Fisheries and Aquaculture Proceedings No. 20. Rome, FAO, 202 pages.

Food and Agriculture Organization of United Nations (FAO) (2008). Climate change for fisheries and aquaculture. Technical background document from the expert consultation. FAO, Rome, 18 pages.

Intergovernmental Panel on Climate Change (IPCC) (2007). Climate change: Impacts, adaptation, and vulnerability. Contribution of working group II to the fourth assessment report of the intergovernmental panel on climate change. Cambridge University Press, 987 pages.

Islam, M.M., Barman, A., Kundu, G.K., Kabir M.A., \& Paul, B. (2019). Vulnerability of inland and coastal aquaculture to climate change: Evidence from a developing country. Aquaculture and Fisheries. 4(5): 183-189.

Mai, L.T.P. (2017). The study on impact of salinity intrusion and adaption of aquaculture farming in the Mekong delta (doctoral dissertation). Can Tho University (in Vietnamese).

Mai, L.T.P., Son, V.V., Huong, D.T.T., Ni, D.V., \& Hai, T.N., 2016a. Evaluation of impacts salinity to snakeskin gourami (Trichogaster pectoralis) and ability of farming in salinity intrusion condition by climate change in Hau Giang province. Can Tho University Journal of Science. 43(B): 133-142 (in Vietnamese).

Mai, L.T.P., Son, V.V., Ni, D.V., \& Hai, T.N. (2016b). Evaluation of impacts and solutions to deal with the climate change in the improved extensive culture system in the Mekong Delta. Can Tho University Journal of Science, 42(B): 28-39 (in Vietnamese).

Mai, L.T.P., Son, V.V., Huong, D.T.T., Hai, T.N., \& Ni, D.V. (2015). Evaluation of impacts and solutions to deal with the climate change in the rice-shrimp system in the Mekong Delta. Can Tho University Journal of Science, 41(B): 121-133 (in Vietnamese).

Nicholls, R.J. (2006). Climate stabilization and impacts of sea-level rise. In H.J., Schellnhuber, Cramer, W., Nakicenovic, N., Wigley, T.M.L., \& Yohe, G., (Eds), Avoiding dangerous climate change (pp. 195202). Cambridge University Press, Cambridge, UK.

Shelton, C. (2014). Climate change adaptation in fisheries and aquaculture - compilation of initial examples. FAO Fisheries and Aquaculture, No. 1088, FAO, Rome.

Soto, D., Ross, L.G., Handisyde, N., Bueno, P.B., Beveridge, M.C.M, Dabbadie, L., Aguilar-Manjarrez, J., Cai, J., \& Pongthanapanich, T. (2018). Climate change and aquaculture: Vulnerability and adaptation options. In M. Barange, Bahri, T., Beveridge, M.C.M., Cochrane, K.L., Funge-Smith, S.,\& F., Poulain, (Eds.), Impacts of climate change on fisheries and aquaculture: Synthesis of current knowledge, adaptation, and mitigation options (pp. 465-490). FAO Fisheries and aquaculture technical paper, No. 627. FAO, Rome.

Tuan, L.A., \& Suppakorn, C. (2011). Climate change in the Mekong River Delta and key concerns on future climate threats. In M.A, Stewart \& P. A., Coclanis (Eds.), Environmental change and agricultural sustainability in the Mekong Delta (pp. 207-217). Advances in Global Change Research 45, Springer Science+Business Media B.V. 
United Nations Framework Convention on Climate Change (UNFCCC). (2003). Vietnam initial national communication. Socialist Republic of Viet Nam. Ministry of Natural Resources and Environment, Ha Noi.
United States Environmental Protection Agency (USEPA) (2012). Climate change indicators in the United States, 2012. Technical documentation. USEPA.

Vietnam National University - HCM City and Geomatics Center. (2019). General of Mekong delta in Vietnam. Retrieved June 19, 2019 from

https://mgis.vn/DBSCL\%23dialy 